\title{
KONSENTRASI KLOROFIL DAUN PADI PADA SAAT KEKURANGAN AIR YANG DIINDUKSI DENGAN POLIETILEN GLIKOL
}

\author{
Yunia E. Banyo ${ }^{1)}$, Nio Song Ai ${ }^{1)}$, Parluhutan Siahaan ${ }^{1)}$, Agustina M. Tangapo ${ }^{1)}$ \\ 1)Program Studi Biologi FMIPA Universitas Sam Ratulangi \\ Jl. Kampus Unsrat Manado 95115 \\ e-mail: banyoyunia@yahoo.com; nio_ai@yahoo.com; \\ luhut_siahaan68@yahoo.co.id; iin truly@yahoo.co.id
}

\begin{abstract}
ABSTRAK
Telah dilakukan penelitian mengenai konsentrasi klorofil daun padi (Oryza sativa L.) kultivar Serayu dan IR 64 pada saat kekurangan air yang diinduksi dengan polietilen glikol (PEG). Penelitian ini bertujuan untuk membandingkan konsentrasi klorofil total, klorofil a dan klorofil b pada daun padi pada saat kekurangan air yang diinduksi dengan PEG 8000 dengan mengkultur tanaman padi pada medium dengan potensial air (PA) $0 ;-0,5$ dan -1 MPa. Sampel helaian daun (lamina) untuk tiap perlakuan diambil sebanyak $1 \mathrm{~g}$, dihaluskan dengan mortar dan pestel, lalu diekstraksi dengan alkohol 95\% sampai semua klorofil terlarut. Ekstrak disaring dan supernatan ditampung dalam labu ukur $100 \mathrm{ml}$, lalu ditambahkan alkohol 95\% sampai $100 \mathrm{ml}$. Konsentrasi klorofil diukur dengan spektrofotometer pada panjang gelombang 649 dan $665 \mathrm{~nm}$. Berdasarkan hasil yang diperoleh, tanaman padi kultivar Serayu dan IR 64 mulai mengalami kekeringan pada PEG dengan PA -0,5 MPa dengan ciri-ciri daun yang kering, menggulung dan batang yang berwarna kecoklatan. Perbedaan konsentrasi klorofil total, klorofil a, dan klorofil b pada daun padi kultivar Serayu dan IR 64 diamati pada PEG dengan PA 0; -0,5 dan -0,1 MPa.
\end{abstract}

Kata kunci: konsentrasi klorofil, polietilen glikol (PEG), kekurangan air, padi kultivar Serayu dan IR 64

\section{THE CHLOROPHYLL CONCENTRATION IN RICE LEAVES UNDER POLYETHYLENE-GLYCOL- INDUCED WATER DEFICIT}

\begin{abstract}
A research was conducted to evaluate the concentrations of total clorophyll, chlorophyll a and clorophyll b in rice (Oryza sativa $\mathrm{L}$.) leaves under polyethylene-glycol-induced water deficit. The water deficit was induced by culturing the plants in medium containing polyethylene glycol (PEG) 8000 with water potential (PA) 0;-0,5; and $\quad-1 \mathrm{MPa}$ for 2 days. Leaf lamina (1 g) was sampled from each treatment at day 0 and 2. Each sample was ground using porcelain mortar and pestle, and extracted with $95 \%$ ethanol until all chlorophyll was dissolved. The extract was filtered, the supernatant was collected in $100 \mathrm{ml}$ flask and added with 95\% ethanol until $100 \mathrm{ml}$. The chlorophyll concentration was measured using spechtrophotometer at 649 and $665 \mathrm{~nm}$. The dry and rolled leaves and brown stems were observed in cultivar Serayu and IR 64 that were cultivated in media containing PEG with PA $-0,5$ and $-1,0 \mathrm{MPa}$. The concentrations of total chlorophyll, chlorophyll a and $\mathrm{b}$ in leaves of cultivar Serayu and IR 64 cultivated in media containing PEG with PA 0; -0,5 and -1,0 MPa were different.
\end{abstract}

Keywords: chlorophyll concentration, polyethylene glycol (PEG), water deficit, Serayu and IR 64 rice cultivars

\section{PENDAHULUAN}

Kekurangan air mempengaruhi semua aspek pertumbuhan tanaman, yang meliputi proses fisiologi, biokimia, anatomi dan morfologi. Pada saat kekurangan air, sebagian stomata daun menutup sehingga terjadi hambatan masuknya $\mathrm{CO}_{2}$ dan menurunkan aktivitas fotosintesis. Selain menghambat aktivitas fotosintesis, kekurangan air juga menghambat sintesis protein dan dinding sel (Salisbury \& Ross, 1995). Tanaman yang mengalami kekurangan 
air secara umum mempunyai ukuran yang lebih kecil dibandingkan dengan tanaman yang tumbuh normal (Kurniasari et al., 2010). Kekurangan air menyebabkan penurunan hasil yang sangat signifikan dan bahkan menjadi penyebab kematian pada tanaman (Salisbury \& Ross, 1995).

Pengukuran karakter fisiologi seperti konsentrasi klorofil, merupakan salah satu pendekatan untuk mempelajari pengaruh kekurangan air terhadap pertumbuhan dan hasil produksi karena parameter ini berkaitan erat dengan laju fotosintesis (Li et al., 2006). Kekurangan air dari tingkat paling ringan sampai paling berat mempengaruhi prosesproses biokimia yang berlangsung dalam sel. Kekurangan air akan menurunkan laju fotosintesis (Fitter \& Hay, 1994; Ju \& Zhang, 1999). Salah satu aspek fotosintesis yang sangat sensitif terhadap kekurangan air adalah biosintesis klorofil dan pembentukan protoklorofil terhambat pada potensial air sedikit di bawah 0 atm (Salisbury \& Ross, 1992).

Beberapa hasil penelitian yang telah dilakukan untuk mempelajari respons padi terhadap kekurangan air adalah protein 18 $\mathrm{kDa}$ yang dapat dikaitkan dengan toleransi kalus padi terhadap kekeringan (Nio, 1996); lebih tingginya kandungan protein kalus padi yang dikultur pada medium dengan potensial air $-2 \mathrm{~atm}$ dibandingkan dengan $0 \mathrm{~atm}$ atau tidak mengalami kekurangan air (Nio et al., 2001); pertambahan berat basah tanaman padi yang kekurangan air lebih kecil daripada yang tidak tercekam (Nio \& Kandou, 2000). Selanjutnya kekeringan pada tanaman padi merupakan salah satu faktor lingkungan yang menghambat fotosintesis (Ju \& Zhang, 1999). Untuk lebih memperkaya wawasan tentang tanggap tanaman padi terhadap kekeringan, perlu diungkapkan lebih lanjut dapat tidaknya kandungan klorofil total, klorofil a dan $b$ dipakai sebagai indikator kekurangan air yang diinduksi dengan polietilen glikol (PEG) pada fase vegetatif tanaman padi.

Berdasarkan latar belakang tersebut maka dilakukan penelitian tentang konsentrasi klorofil daun tanaman padi (Oryza sativa L.) pada saat kekurangan air yang diinduksi dengan polietilen glikol. Penelitian ini berkaitan dengan masalah pengaruh kekurangan air terhadap konsentrasi klorofil total, klorofil a dan $b$ pada daun tanaman padi. Kekurangan air yang dimaksud dalam penelitian ini adalah pengurangan potensial air (PA) dengan menambahkan polietilen glikol (PEG) sesuai dengan PA yang diinginkan. Dalam penelitian ini akan diuji 3 macam medium, yaitu medium dengan PA $0 ;-0,5$ dan -1 $\mathrm{MPa}$. Kekurangan air yang diaplikasikan termasuk kategori ringan. Hipotesis yang diuji dalam penelitian ini ialah adanya perbedaan konsentrasi klorofil total, klorofil a dan $b$ pada daun tanaman padi yang dikultur pada medium dengan PA $0 ;-0,5 ;-1 \mathrm{MPa}$.

\section{METODOLOGI PENELITIAN}

\section{a. Tempat dan Waktu Penelitian}

Penelitian dilakukan dari Juli hingga September 2012. Penelitian ini dilakukan di Laboratorium Biokonservasi dan di Laboratorium Bioteknologi Jurusan Biologi, FMIPA Universitas Sam Ratulangi.

\section{b. Bahan dan Cara Kerja}

Bahan penelitian yang digunakan yaitu benih tanaman padi kultivar Serayu dan IR 64 dan, alkohol 95\%, polietilen glikol (PEG) 8000 , akuades, pupuk Gandasil D. Benih padi diperoleh dari Balai Pengawasan Sertifikasi Benih Tanaman Pangan dan Hortikultura Provinsi Sulawesi Utara. Peralatan yang digunakan adalah spektrofotometer tipe Genesis 20, hot plate, timbangan analitik, tabung reaksi, rak tabung reaksi, labu ukur, gelas ukur, batang pengaduk, busa, mortar dan pestel, tisu, alat tulis, kertas label, saringan, gunting, dan kamera digital.

Penelitian ini merupakan percobaan faktorial dalam rancangan acak lengkap dengan 3 perlakuan dan 3 ulangan pada 2 kultivar tanaman padi yaitu IR 64 dan Serayu. Peubah bebas dalam penelitian ini adalah 3 macam perlakuan kekeringan yaitu larutan PEG dengan potensial air (PA) yaitu 0; -0,5 dan -1 MPa. Larutan PEG dengan PA yaitu $0 ;-0,5$ dan $-1 \mathrm{MPa}$ dibuat dengan menambahkan $0 \mathrm{~g}, 198 \mathrm{~g}$ dan $287 \mathrm{~g}$ PEG 8000 ke dalam 1 L larutan medium basal (Michel, 1983). Medium basal yang digunakan adalah larutan Gandasil D 0,025\% yang mengandung $\mathrm{N}(20 \%), \mathrm{P}_{2} \mathrm{O}_{5} \quad(15 \%)$, $\mathrm{K}_{2} \mathrm{O}(15 \%), \quad \mathrm{MgSO}_{4}(1 \%), \mathrm{Mn}, \mathrm{B}, \mathrm{Cu}, \mathrm{Co}$, $\mathrm{Zn}$, aneurine, lactoflavine dan nicotinic acid amide. Peubah terikatnya ialah konsentrasi klorofil total, klorofil a dan b pada daun tanaman padi setelah 2 hari perlakuan. 
Benih padi dikecambahkan pada tanah yang digenangi air dalam bak plastik yang tidak dilubangi, sehingga air yang disiramkan hanya hilang karena evapotranspirasi. Perkecambahan dilakukan selama 3 minggu. Tanaman muda hasil perkecambahan yang berumur 3 minggu akan dikultur pada medium yang berupa larutan PEG dengan PA yaitu $0 ;-0,5$ dan $-1 \mathrm{MPa}$ selama 2 hari. Konsentrasi klorofil pada daun padi ditentukan dengan cara sampel helaian daun (lamina) untuk tiap perlakuan diambil sebanyak $1 \mathrm{~g}$, dihaluskan dengan mortar dan pestel, lalu diekstraksi dengan alkohol 95\% sampai semua klorofil terlarut. Konsentrasi klorofil total, klorofil a dan klorofil b dihitung dengan metode Wintermans \& de Mots (1965) dalam Sasmitamihardja (1990) sebagai berikut:

Klorofil total $(\mathrm{mg} / \mathrm{L})=20,0 \mathrm{OD}_{649}+6,1 \mathrm{OD}_{665}$ Klorofil a $(\mathrm{mg} / \mathrm{L})=13,7 \mathrm{OD}_{665}-5,76 \mathrm{OD}_{649}$ Klorofil b (mg/L)=25,8 OD $649-7,7 \mathrm{OD}_{665}$ $(\mathrm{OD}=$ Optical density $=$ Nilai absorbansi $)$

\section{c. Analisis data}

Data dianalisis dengan Anova. Jika ada perbedaan nyata akan diuji lanjut dengan BNT 5\% (Sastrosupadi, 2000; Hanafiah, 2004).

\section{HASIL DAN PEMBAHASAN}

Pada kondisi kontrol, faktor kultivar menyebabkan perbedaan konsentrasi klorofil total. Konsentrasi klorofil total dari daun padi kultivar Serayu lebih tinggi

$(31.27 \pm$ $0.31) \mathrm{mg} / \mathrm{L}$ daripada kultivar IR 64 (29.95 \pm $0.42) \mathrm{mg} / \mathrm{L}$ (Gambar 1). Hal ini disebabkan oleh perbedaan proses metabolisme yang berkaitan dengan umur tanaman, umur daun, morfologi dan faktor genetik (Biber, 2007). Lama fase vegetatif kultivar IR 64 berbeda dengan kultivar Serayu. Perbedaan lama fase vegetatif mengakibatkan perbedaan umur tanaman. Umur tanaman kultivar IR 64 yaitu 115 hari dengan fase vegetatif 45 hari, sedangkan umur tanaman kultivar Serayu yaitu 120-130 hari dengan fase vegetatifnya selama 65 hari (IRRI, 2007). Pada perlakuan kekurangan air yang diinduksi dengan PEG selama 2 hari, faktor PEG menyebabkan perbedaan konsentrasi klorofil total daun pada kultivar IR 64 dan Serayu. Konsentrasi klorofil total pada perlakuan PEG -0,5 dan -1 $\mathrm{MPa}$ lebih tinggi daripada $\mathrm{PEG} 0 \mathrm{MPa}$
(Gambar 1). Perlakuan PEG -0,5 dan -1 MPa menurunkan potensial air pada medium sehingga air dari medium dihambat untuk masuk ke dalam jaringan tumbuhan melalui akar atau dengan kata lain mengalami kekurangan air. Tidak tersedianya air merupakan salah satu cekaman abiotik yang menghambat pertumbuhan dan perkembangan suatu tanaman. Air juga merupakan reagent yang penting dalam fotosintesis dan reaksi-reaksi hidrolisis (Nio \& Banyo, 2011). Peranan air yang penting ini menimbulkan konsekuensi bahwa kekurangan air akan mempengaruhi semua proses metabolisme tanaman baik secara langsung atau tidak langsung (Pugnaire \& Pardos, 1999 dalam Lestari, 2005), termasuk sintesis klorofil.

Pada kondisi kontrol, konsentrasi klorofil a pada daun padi kultivar IR 64 lebih tinggi daripada kultivar Serayu (Gambar 2). Perbedaan ini disebabkan oleh faktor kultivar dan hari. Kultivar IR 64 merupakan padi gogo yang berumur pendek hidup di lahan kering tanpa penggenangan air, sedangkan Serayu merupakan padi sawah yang seluruh waktu pertumbuhannya digenangi air (Anonim, 2012). Oleh sebab itu, konsentrasi klorofil a pada kultivar IR 64 lebih tinggi $(21.01 \pm 1.36) \mathrm{mg} / \mathrm{L}$ daripada kultivar Serayu $(17.78 \pm 2.05) \mathrm{mg} / \mathrm{L}$. Perbedaan konsentrasi klorofil a pada perlakuan kekurangan air selama 2 hari yang diinduksi oleh PEG disebabkan oleh faktor PEG. Konsentrasi klorofil a pada kultivar IR 64 dan Serayu yang ditumbuhkan di larutan PEG -0,5 dan -1 MPa lebih tinggi daripada di larutan 0 $\mathrm{MPa}$. Hasil ini berbeda dengan penelitian Nio (2010) yang menginformasikan bahwa konsentrasi klorofil a pada daun padi yang ditumbuhkan pada medium dengan PA 0 MPa lebih tinggi daripada yang ditumbuhkan pada medium dengan potensial air (PA) - 0,5 dan -1 MPa selama 1 bulan. 


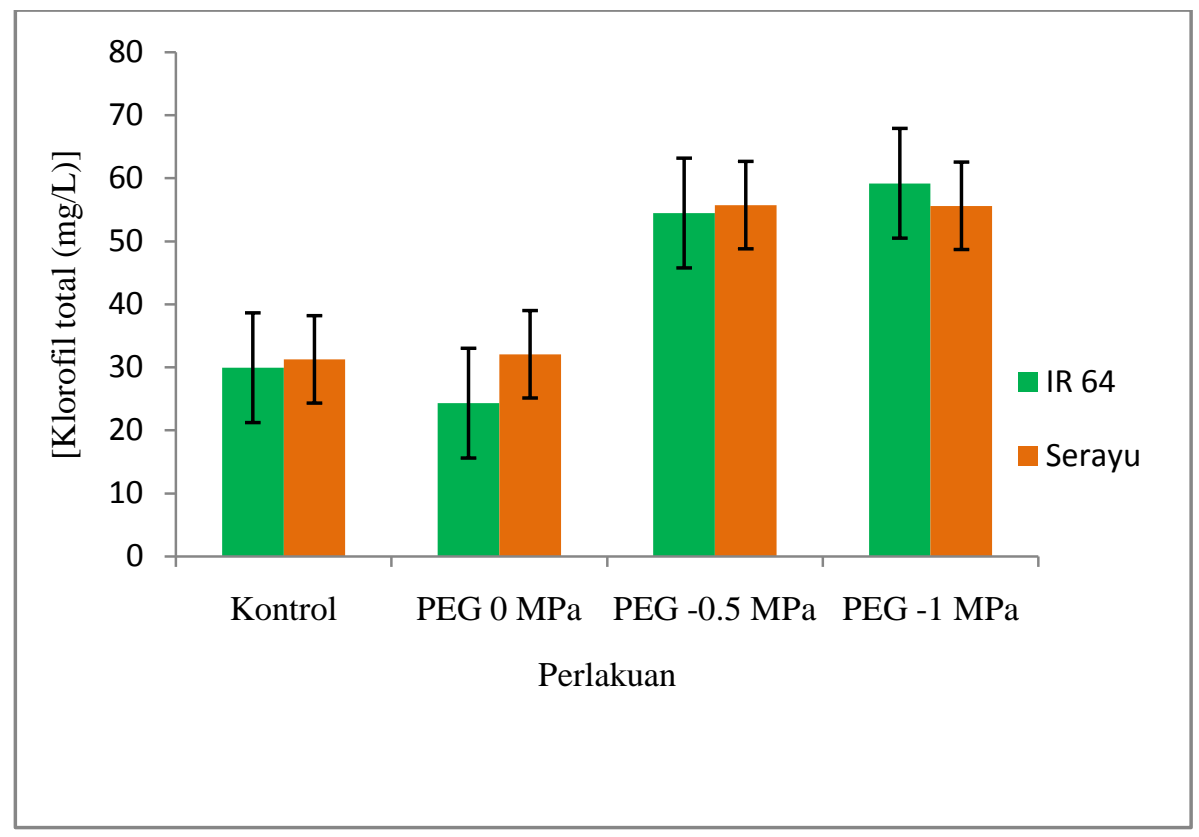

Gambar 1. Konsentrasi klorofil total (mg/L) daun padi kultivar IR 64 dan Serayu pada kondisi kontrol dan kekurangan air selama 2 hari (rata-rata \pm standar deviasi)

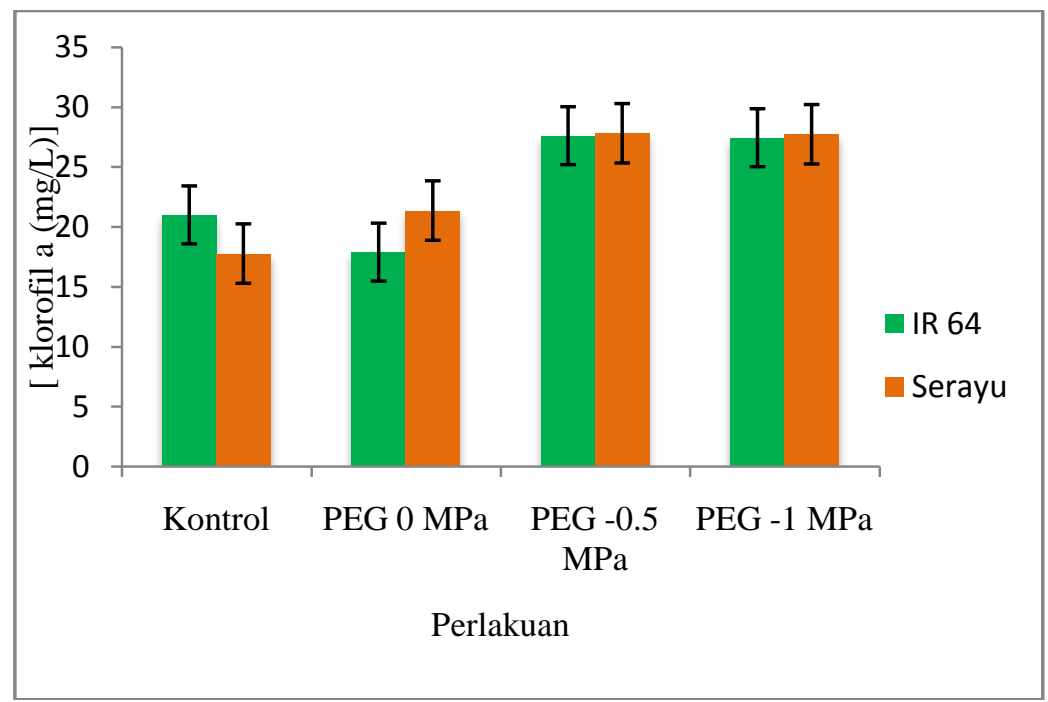

Gambar 2. Konsentrasi klorofil a (mg/L) daun padi kultivar IR 64 dan Serayu pada kontrol dan kekurangan air selama 2 hari (rata-rata \pm standar deviasi)

Konsentrasi klorofil b daun padi kultivar IR 64 dan Serayu (Gambar 3) pada kondisi kontrol (hari ke-0) tidak berbeda dengan pada perlakuan PEG 0 MPa (hari ke-2). Hasil ini menunjukkan bahwa pemindahan tanaman padi dari media campuran tanah, kompos dan sekam ke media basal (PEG 0 MPa) yang ditumbuhkan selama 2 hari tidak mengganggu sintesis klorofil $b$. Konsentrasi klorofil $b$ daun padi pada perlakuan PEG -0,5 dan -1 MPa lebih tinggi daripada PEG $0 \mathrm{MPa}$ (Gambar 3).
Hasil ini berbeda dengan penelitian Prihastanti (2010) yang menunjukkan bahwa konsentrasi klorofil b pada semai kakao dengan kandungan air tanah 50\% lebih rendah dibandingkan perlakuan air tanah $70 \%$ selama 2 bulan. Kekurangan air menyebabkan perbedaan respons fisiologi dan biokimia pada tanaman. Pembentukan klorofil akan optimal apabila kondisi lingkungan mampu mendukung proses fisiologi, di antaranya ketersediaan air. 
Tanaman yang tetap hijau dapat meningkatkan produksi dan efisiensi transpirasi pada saat tanaman mengalami kekurangan air, seperti pada sorgum, jagung dan gandum (Li et al., 2006). Hasil penelitian van der Mescht et al. (1999) menunjukkan bahwa daun kentang yang mengalami kekurangan air selama 4 minggu memiliki kandungan klorofil a, klorofil $\mathrm{b}$, dan klorofil total lebih rendah dibandingkan dengan tanaman kentang yang diberi air yang cukup, tetapi kandungan klorofil a, kandungan klorofil b dan klorofil total tersebut pada kentang bervariasi dan tidak dapat menggambarkan sensitivitas atau toleransi terhadap kekurangan air dengan jelas.

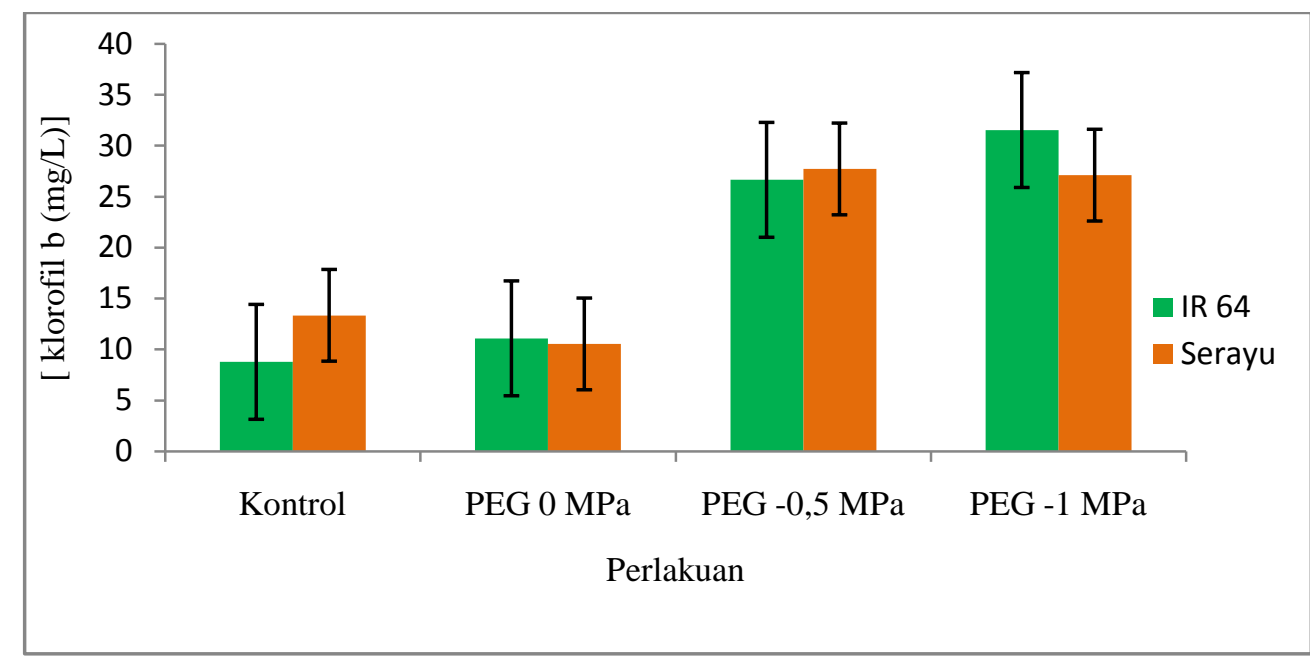

Gambar 3. Konsentrasi klorofil b (mg/L) O. sativa kultivar IR 64 dan Serayu pada kontrol dan kekurangan air selama 2 hari (rata-rata \pm standar deviasi)

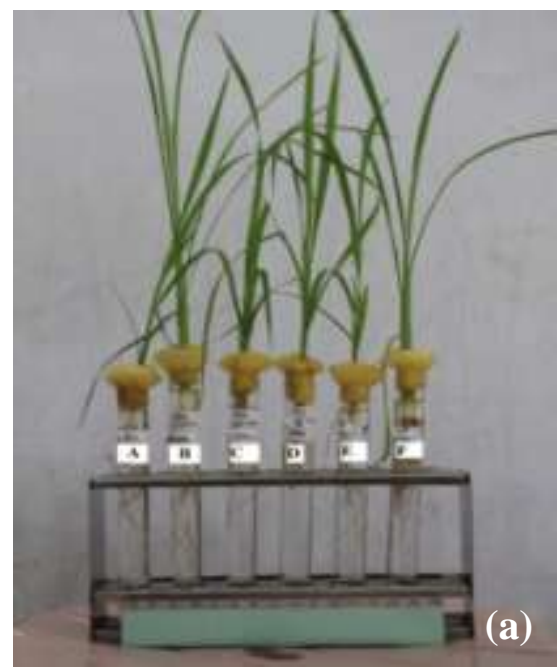

Keterangan:

A (Kultivar Serayu pada PEG -1 MPa) B (Kultivar IR 64 pada PEG -1 MPa)

C (Kultivar Serayu pada PEG -0,5 MPa)

D (Kultivar IR 64 pada PEG -0,5 MPa)

E (Kultivar Serayu pada PEG $0 \mathrm{MPa}$ )

F (Kultivar IR 64 pada PEG $0 \mathrm{MPa}$ )

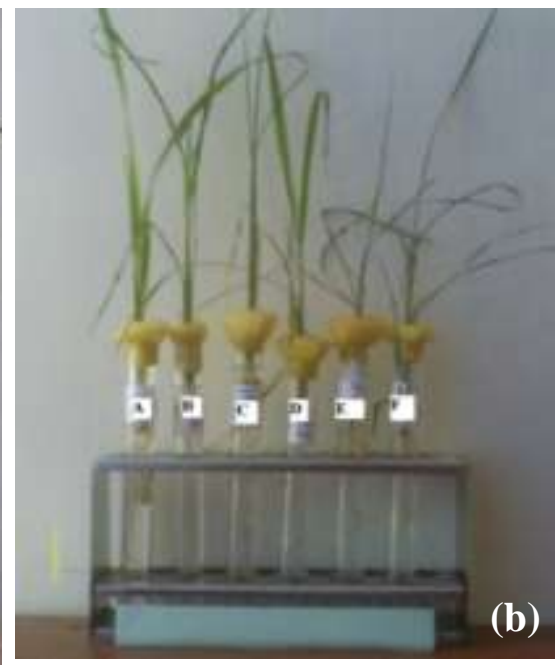

Keterangan:

A (Kultivar IR 64 pada PEG 0 MPa) B (Kultivar IR 64 pada PEG -0,5 MPa)

C (Kultivar IR 64 pada PEG -1 MPa)

D (Kultivar Serayu pada PEG $0 \mathrm{MPa}$ )

E (Kultivar Serayu pada PEG -0,5 MPa)

F (Kultivar Serayu pada PEG -1 MPa)

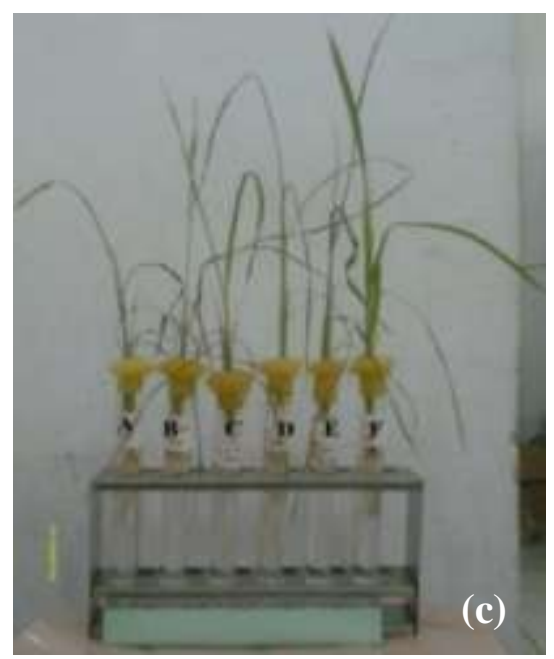

Keterangan:

A (Kultivar Serayu pada PEG -1 MPa) B (Kultivar Serayu pada PEG -0,5 MPa)

C (Kultivar Serayu pada PEG $0 \mathrm{MPa}$ )

D (Kultivar IR 64 pada PEG -1 MPa)

E (Kultivar IR 64 pada PEG -0,5 MPa)

F (Kultivar IR 64 pada PEG $0 \mathrm{MPa}$ )

Gambar 4. Tanaman padi kultivar Serayu dan IR 64 pada perlakuan kekurangan air yang iinduksi PEG pada hari ke-0 (a), 1 (b) dan 2 (c)

Konsentrasi klorofil total dan klorofil a pada kultivar Serayu yang ditumbuhkan di larutan PEG 0 MPa selama 2 hari lebih besar daripada konsentrasinya pada kondisi kontrol. 
Tetapi pada kultivar IR 64 konsentrasi kedua macam tersebut pada daun padi yang ditumbuhkan di larutan PEG 0 MPa selama 2 hari lebih rendah daripada kondisi kontrol. Hal ini disebabkan oleh perbedaan kemampuan adaptasi dari kedua kultivar tersebut. Tanaman padi kultivar IR 64 dan Serayu pada penelitian ini dipindahkan dari media tanah kompos ke media cair (dalam tabung reaksi) diletakkan dalam ruangan terbuka dengan intensitas sedang selama 2 hari. Setelah dipindahkan ke larutan PEG 0 MPa dalam waktu 2 hari kultivar IR 64 beradaptasi lebih baik dibandingkan dengan kultivar Serayu (Gambar 4c).

Pada penelitian ini, konsentrasi klorofil total, klorofil a dan klorofil $b$ pada PEG 0 MPa lebih rendah daripada -0,5 dan -1 MPa. Hal ini disebabkan karena pada saat tanaman padi ditumbuhkan pada larutan PEG -0,5 dan -1 MPa selama 2 hari, daun padi tampak mulai mengering dan menggulung (Gambar 4c). Oleh sebab itu perlakuan segera diakhiri lalu konsentrasi klorofil segera diukur. Keadaan daun padi tersebut menunjukkan sejumlah besar air keluar dari daun akibat kekurangan air. Sampel daun dengan berat basah yang sama untuk perlakuan PEG 0 MPa mempunyai jumlah sel yang lebih sedikit daripada sampel daun dari perlakuan PEG -0,5 dan -1 MPa. Hal ini yang menyebabkan peningkatan konsentrasi klorofil total, klorofil a, dan klorofil b pada kedua perlakuan tersebut. Hasil penelitian ini menunjukkan bahwa pengukuran konsentrasi klorofil daun tanaman yang mengalami kekurangan air sebaiknya menggunakan satuan luas jaringan daun bukan berdasarkan berat basah.

Pada hari hari ke- 0 tanaman padi kultivar IR 64 dan Serayu pada kondisi kontrol (PEG 0 MPa) tidak mengalami perubahan baik pada daun maupun batang. Daun dan batangnya masih tetap hijau dan segar (Gambar 4a). Setelah hari hari ke-1 tampak perubahan pada kultivar Serayu (Gambar 4b). Satu helaian daun di bagian ujung mulai menggulung dan pada hari ke-2 satu helaian daunnya menggulung dan tampak kering dengan batang yang mulai berwarna kecoklatan sedangkan pada kultivar IR 64 tidak mengalami perubahan pada daun dan batangnya yang tetap hijau segar.

Tanaman padi kultivar IR 64 dan Serayu pada hari ke-0 yang diberi perlakuan dengan PEG pada PA -0,5 MPa dan -1 MPa terlihat subur dan berwarna kehijauan (Gambar 4a), setelah hari ke-1 mulai terjadi perubahan. Pada kultivar Serayu dengan PEG pada PA - 0,5 MPa tanaman tidak mampu lagi mentolerir adanya senyawa tersebut sehingga mulai mengalami kekurangan air dengan ciriciri daun tampak kering dan menggulung serta berwarna kecoklatan pada bagian batangnya (Gambar 4b) pada kultivar IR 64 hanya terjadi perubahan pada daun yang menggulung sedangkan batangnya tetap hijau. Perubahan ini juga terjadi pada hari ke2 , tanaman semakin tercekam dan mengering. Pada perlakuan PEG -1 MPa tanaman padi kultivar Serayu pada hari ke-1 tanaman tersebut mengalami kekurangan air yang ditandai dengan daunnya yang kering dan menggulung dan pada hari ke-2 beberapa daun tanaman tersebut berwarna kekuningan dengan batang yang berwarna kecoklatan. Pada kultivar IR 64 pada hari ke- 1 daunnya menggulung dan mengering dengan batang yang tetap hijau sedangkan pada hari ke-2 batangnya berubah warna menjadi kecoklatan (Gambar 4c).

Hasil penelitian ini menunjukkan bahwa tanaman padi yang mengalami perlakuan yang berbeda yaitu pemberian PEG yang berbeda akan menunjukkan tampilan fisik yang berbeda pula setelah diperlakukan selama 2 hari. Tampilan daun yang menggulung dan mengering yang dimulai dari hari pertama dan semakin besar tingkat dan banyaknya daun yang menggulung dan mengering memberi petunjuk bahwa daun tidak akan dapat melakukan aktivitas metabolisme. Daun yang mengering dan menggulung mengindikasikan bahwa daun tidak mampu lagi menyerap unsur-unsur hara dari medium, sehingga tidak akan mampu melanjutkan proses metabolisme, termasuk proses pembentukan klorofil daun. Dalam hal, jumlah klorofil yang lebih tinggi pada perlakuan yang mengalami kekurangan air akibat pemberian PEG semata-mata disebabkan oleh teknik pengukuran dan pengambilan sampel yang masih perlu dilakukan perbaikan. Dalam hal ini, teknik pengambilan data yang lebih baik akan dilakukan pada penelitian lebih lanjut. Teknik yang dapat dicoba untuk mengukur konsentrasi klorofil yaitu pengambilan sampel berdasarkan luas daun atau dengan 
cara pengeringan sampel daun pada suhu $40^{\circ} \mathrm{C}$ selama $24 \mathrm{jam}$.

\section{KESIMPULAN}

1. Terdapat perbedaan konsentrasi klorofil total, klorofil a, dan klorofil b pada daun padi kultivar Serayu dan IR 64 pada saat kekurangan air yang diinduksi dengan PEG pada PA - 0 ; $-0,5$ dan -0,1 MPa.

2. Tanaman padi kultivar Serayu dan IR 64 mulai mengalami kekurangan air pada larutan PEG dengan PA -0,5 MPa dengan ciri-ciri daun yang kering, menggulung dan batang yang berwarna kecoklatan.

3. Perbedaan tampilan fisik daun yang kering, menggulung dan batang berwarna kecoklatan merupakan indikasi tumbuhan mengalami gangguan dalam proses metabolisme maupun proses fisiologi lainnya. Terhambatnya proses ini juga akan mempengaruhi proses pembentukan klorofil.

4. Perlu dilakukan penelitian lanjutan tentang konsentrasi klorofil yang kekurangan air dengan kultivar yang lebih banyak, waktu yang lebih lama, dan potensial air medium yang lebih rendah.

5. Perlu dilakukan penelitian dengan teknik yang berbeda untuk mengukur konsentrasi klorofil dengan cara pengambilan sampel berdasarkan luas daun atau dengan cara pengeringan daun pada suhu $40^{\circ} \mathrm{C}$ selama 24 jam.

\section{DAFTAR PUSTAKA}

$$
\begin{array}{lr}
\text { Anonim. } & 2012 . \\
\text { http://id.wikipedia.org/wiki/Padi } & \text { Padi. } \\
\text { Agustus 2012]. } &
\end{array}
$$

Biber, P.D. 2007. Evaluating a Chlorophyll Content Meter on Three Coastal Wetland Plant Species. J. Agricultural, Food and Environmental Sciences. 1 (2): p. 1-11

Fitter, A.H and R.K.M. Hay. 1994. Fisiologi Lingkungan Tanaman. Gadjah Mada University Press, Yogyakarta.

Hanafiah, K.A. 2004. Rancangan Percobaan dan Teori Aplikasi. Fakultas Pertanian Universitas Sriwijaya, Palembang.
[IRRI] Internasional Rice Research Institute. 2007. Rice Knowledge Bank. www.knowledgebankirri.org/morph welcome_to_Mophology_of_the_Rice _Plant.htm [18 September 2012].

Ju,C and J. Zhang. 1999. Effect of Water Stress on Photosystem II Photochemistry and its Thermostability in Wheat Plants. J. Exp. Bot. 50 (336): p.1196-1206.

Kurniasari, A.M., Adisyahputra dan R.Rosman. $2010 . \quad$ Pengaruh Kekeringan pada Tanah Bergaram Nacl terhadap Pertumbuhan Tanaman Nilam. Bul. Littro. 21 (1): p.18- 27.

Lestari. 2005. Hubungan antara Kerapatan Stomata dengan Ketahanan Kekeringan pada Somaklon Padi Gajahmungkur, Towuti, dan IR 64. Balai Besar Penelitian dan Pengembangan Bioteknologi dan Sumberdaya Genetik Pertanian (Balitbiogen), Bogor.

Li, R.P.G., M. Baum, S. Grando and S.Ceccarelli. 2006. Evaluation of Chlorophyll Content and Fluorescence Parameters as Indicators of Drought Tolerance in Barley. Agricultural Sciences in China. 5 (10): p.751-757.

Michel, B.E. 1983. Evaluation Of The Water Potertials of Solutions Of Polyethylene Glycol 8000 Both In The Absence And Presence Of Other Solutes. Plant Physiol. 72: p.66-70.

Nio, S.A. 1996. Aktivitas Peroksidase dan Profil Protein Lini Kalus Padi (Oryza sativa L.) Toleran Kekeringan [Tesis]. ITB, Bandung.

Nio, S.A. dan F.E.F.Kandou. 2000. Respons Pertumbuhan Padi (Oryza sativa L.) Sawah dan Gogo pada Fase Vegetatif Awal Terhadap Kekurangan air. Eugenia. 6: p.270-273.

Nio, S.A.,W. Tilaar dan J. Assa. 2001. Analisis Pertumbuhan dan Kandungan Protein pada Kalus Padi (Oryza sativa L.) Sawah yang Mengalami Kekurangan Air. Eugenia 7: p.208212. 
Nio, S.A. 2010. Pengujian Kandungan Klorofil Total, Klorofil A dan B sebagai Indikator Kekurangan Air pada Padi (Oryza sativa L.). J. Ilmiah Sains. 10: p.86-90.

Nio, S.A. dan Y. Banyo. 2011. Konsentrasi Klorofil Daun sebagai Indikator Kekurangan Air pada Tanaman. $J$. Ilmiah Sains. 11 (2): p. 167-173.

Prihastanti. 2010. Kandungan Klorofil Dan Pertumbuhan Semai Kakao (Theobroma cacao L.) pada Perlakuan Kekurangan air Yang Berbeda. $J$. Bioma. 12 (2): p.35-39.

Salisbury, F.B. dan C.W. Ross. 1992. Plant Physiology. 4rd ed. Wadsworth Publishing Company, California.
1995. Fisiologi Tumbuhan. Jilid 2. Penerbit ITB, Bandung.

Sastrosupadi. 2000. Rancangan Percobaan Praktis Bidang Pertanian. Edisi Revisi. Penerbit Kanisius, Jakarta.

Sasmitamihardja, D. 1990. Penuntun Praktikum Fisiologi Tumbuhan. ITB, Bandung.

van der Mescht A., J.A.de Ronde and F.T.Rossouw. 1999. Chlorophyll fluorescence and chlorophyll content as a measure of drought tolerance in potato. South African J. of Science. 95: p. 407-412. 